\title{
Ethical and legal bird hunting duties by Polish veterinarians
}

\author{
MARIUSZ Z. FELSMANN, JÓZEF SZAREK*, \\ IRENEUSZ SOŁTYSZEWSKI ${ }^{* *}$, JUSTYNA KARAŹNIEWICZ ${ }^{* \star *}$
}

\author{
Department of Fundamental and Preclinical Sciences, Faculty of Biological and Veterinary Sciences, \\ Nicolaus Copernicus University in Toruń, Gagarina 7, 87-100 Toruń, Poland \\ *Department of Pathophysiology, Forensic Veterinary Medicine and Administration, \\ University of Warmia and Mazury in Olsztyn, Oczapowskiego 13, 10-719 Olsztyn, Poland \\ **Department of Large Animal Diseases with Clinic, Faculty of Veterinary Medicine, \\ Veterinary Research Centre and Center for Biomedical Research, Warsaw University of Life Sciences WULS - SGGW, \\ Nowoursynowska 100, 02-797 Warsaw, Poland \\ ***Department of Criminal Procedure, University of Warmia and Mazury in Olsztyn, \\ Dybowskiego 11, 10-719 Olsztyn, Poland
}

Felsmann M. Z., Szarek J., Sołtyszewski I., Karaźniewicz J. Ethical and legal bird hunting duties by Polish veterinarians

\section{Summary}

Polish veterinarians are committed to specific behaviors. They have an obligation to actively prevent pollution of the natural environment and threats to public health. The law does not prohibit them from hunting though. Hunting birds with lead ammunition is harmful to the environment, birds and humans. In view of the above, it seems that this type of hunting should be forbidden to veterinarians. Unfortunately, Polish law makes it impossible to punish veterinary surgeons for bird hunting with lead ammunition. As hunters, veterinarians are probably aware of the harmfulness of such behavior, but they prioritize their pleasure over environmental concerns. This study examines Polish legal acts related to hunting by veterinarians and presents specific legal provisions requiring and forbidding specific behaviors of veterinarians. According to the law on the profession of the veterinary surgeon, members of this profession must not engage in bird hunting with lead ammunition. The study discusses the difficulty of changing the current situation and forcing Polish veterinary surgeons to abandon bird hunting with toxic ammunition and to actively fight this practice. Veterinarians, in particular those who are hunters, should actively oppose such forms of hunting that are harmful to the natural environment, especially the hunting of game birds with lead ammunition.

In accordance with veterinary knowledge, ethics and deontology, all veterinarians should inform the public about the harmfulness of eating game animals shot with lead ammunition, in particular with lead pellets.

Keywords: veterinary law and ethics, bird hunting, environmental pollution, lead poisoning

Hunting has been meeting with increasing disapproval. Some aspects of this activity that provoke public protest are addressed by new legislation. Two examples of this are a ban introduced in Poland in 2018 on juveniles participating in hunting and the limitation of the number of game species to just a few in the Netherlands. The veterinary community, as well, is not free from controversy regarding active participation of veterinarians in hunting. So far, however, neither party in the debate has cited legal provisions.

Veterinarians in Poland, as well, are divided about their active participation in hunting. However, this debate does not raise much interest in the Polish National Veterinary Chamber, that is, the veterinary self-government. The few articles on hunting published in the journal of the Polish National Veterinary Chamber (Życie Weterynaryjne) concern only ethical aspects and hardly ever focus on legal ones $(21,31,47)$.

Important as veterinary professional law may be for veterinary surgeons, they have the same legal rights and obligations as other citizens. Poland (according to Article 5 of the Constitution) seeks to ensure, among others, freedom and human rights, as well as environmental protection, and is guided by the principle of sustainable development (57). Freedom, however, is not absolute, but limited by the law to ensure public safety and order, and to protect health and the natural environment (Article 31 section 3 of the Constitution). 
Public authorities are obliged to prevent negative health effects of environmental degradation (Article 68 of the Constitution). In addition, the state shall ensure ecological security and support civic initiatives for environmental protection (Article 74 of the Constitution). Every citizen is obliged to take care of the natural environment and is responsible for his or her negative impact on it (Article 86 of the Constitution). A legal definition of the natural environment is included in the Environmental Protection Act, Article 3 section 39, according to which this concept covers all elements of nature, including biodiversity, and the interaction between these elements (such as human impact) (3).

In light of the normative requirements for environmental protection, it is not surprising that veterinary surgeons may be subject to additional obligations regarding environmental protection, which are directly related to their profession of public trust.

This study analyzes the Polish law regulating veterinarian practice as well as hunting rights. The authors present arguments indicating the need for veterinarians to refrain from participation in certain types of hunting (2). This applies in particular to hunting for game birds $(2,22)$. Moreover, according to the law, Polish veterinarians, both in gremio and in personam, should oppose certain forms of hunting and hunting for certain species of animals (2).

\section{Polish legal norms and participation of veterinarians in hunting}

To begin with, it should be noted that the knowledge of current legal provisions related to the pursuit of the veterinary profession is a statutory duty of a veterinary surgeon from the moment of his receiving the right to practice this profession (2). This study analyzes selected normative acts regulating the practice of the veterinary surgeon and hunting, in particular the Act on the Profession of the Veterinary surgeon and Veterinary Chambers, and the Hunting Law along with executive acts $(1,2)$. The study indicates legal regulations forbidding or requiring veterinarians to take certain actions in specific situations related to their profession.

\section{The Act on the Profession of the Veterinary Surgeon}

The Act on the Profession of the Veterinary Surgeon and Chambers of Veterinary Medicine obliges veterinarians to protect the natural environment and public health. In addition this act requires that this profession be exercised with particular care and in accordance with the principles of veterinary ethics and veterinary deontology (art. 4 of this Act) (Act 1990). Another legal provision imposing an obligation on representatives of this profession to comply with the principles of veterinary ethics and veterinary deontology is provided in Article 19 of the Act (2). Therefore, abidance by the principles of ethics is a legal obligation for veterinarians.
The veterinary Code of Ethics (http://vetpol.org. pl/dmdocuments/Kodeks\%20etyki\%20lekarza\%20 weterynarii.pdf) in Poland is enacted by the National Convention of Veterinary Physicians (Article 37 of the Act on the Profession of the Veterinary Surgeon). For acting in violation of these standards, veterinarians are answerable in veterinary courts. According to this code, the protection of public health and the natural environment is a responsibility of every veterinarian (Article 1 of the Code of Ethics). Article 4 of the Code requires veterinarians to be persons of honesty, integrity and the high personal culture. Article 5 obliges veterinarians to know the current law relevant to their profession. Worth noting are also requirements contained in Article 30 of the Code of Ethics. Subparagraph 1 is worth quoting in its entirety: "It is a responsibility of veterinarians to respect and, if possible, promote animal rights and respect the basic principles of sozology." According to the wording of subparagraph 2 , a veterinarian is obliged to draw the attention of the public and public authorities to irregularities concerning, among others, protection of public health, health protection and ecological threats. The last article of the Code refers to the professionals' liability for non-compliance with the provisions of the Code.

\section{Hunting law and implementing regulations}

The Hunting Law Act (1) defines hunting as, among others, an element of protection of the natural environment, that is, protection of animals in accordance with the principles of ecology (Article 1). According to the Act, one of the purposes of hunting is to protect and shape the natural environment in such a way as to improve the living conditions of animals (Article 3 (2)). The Act prohibits hunting for animals other than legally huntable game species and hunting during the closed season for specific animal species (Article 42aa). Moreover, according to art. 4 par. 3 of this Act, harvesting animals in violation of the conditions of admissibility of hunting is considered poaching.

The ordinance of the Minister of the Environment on the detailed conditions of hunting and marking of carcasses provides a number of rules applicable to hunting (52). Paragraph 6 of the Regulation forbids hunting for birds that are not flying (except hazel grouse (Bonasa bonasia), geese and coot (Fulica atra)) and for unrecognizable birds. Geese and ducks can also be hunted at night ( $(7)$. According to paragraph 13.1., aiming at game and shooting is allowed only after personal and accurate recognition of the game and under conditions that guarantee the effectiveness of the shot and the ability to retrieve the shot game ( $§ 13.2$.). The ordinance makes it possible to carry out mass hunts involving critters and dogs (§ 25).

The Ordinance of the Minister of the Environment specifies more than a dozen species of birds that can be hunted in Poland, including hazel grouse, pheasant (Phasianus colchicus), partridge (Perdix perdix), 
greylag goose (Anser anser), taiga bean goose (Anser fabalis), greater white-fronted goose (Anser albifrons), mallard (Anas platyrhynchos), common teal (Anas crecca), common pochard (Aythya ferina), tufted duck (Aythya fuligula), common wood pigeon (Columba palumbus), Eurasian woodcock (Scolopax rusticola), and coot (Fulica atra) (50).

The ordinance of the Minister of the Environment on establishing hunting periods for game animals contains information on hunting periods, among others, for game birds (51).

In the Polish veterinary community, the issue of veterinary surgeons hunting does not arouse much interest. The few published articles present personal views of their authors rather than legal arguments $(21,31,47)$. This situation indicates the passivity of most veterinary surgeons and their self-government in a matter that is explicitly dealt with by veterinary legislation. This is especially worrying considering the threats resulting from hunting with toxic ammunition, which are presented in a large number of scientific articles.

The above-mentioned legal provisions stipulate that veterinarians should actively protect the natural environment (2). How is it possible to reconcile this obligation with bird hunting by veterinarians using lead shot ammunition? It has long been a well-known fact that this type of ammunition causes lead poisoning in numerous animal species (7-9, 11, 16, 22, 24, 25, 34, $37,39,40,44,53)$. The most commonly used shotgun cartridge No. 4 for shotguns caliber 12, contains about 200 pellets (20). Even in the case of an accurate shot, the vast majority of projectiles fall to the ground or water surface $(22,28)$. For example, if 10 hunters fire only 10 shots each on a hunting run, around 20,000 pellets drop within a small area during a single hunt. During a hunting season, a habitat of bird life (e.g. water reservoir) is used for hunting several times, so the number of pellets in the season increases by an order of magnitude. After ten years, the number of pellets in such a place already reaches millions. Each hunt with lead shot ammunition leads to significant pollution of the natural environment $(8,16,22,28,38,53$, 58-60). In addition, because of the shape and size of lead pellets, many birds swallow them as gastroliths (16, 22, 24, 28). According to legal requirements, veterinarians must be aware of the negative impact of lead on the health and survival of living organisms (not only mammals and birds). Moreover, the law requires veterinarians to refrain from behavior that negatively affects the natural environment.

After leaving the barrel, the shotgun beam expands in the form of a cone. Several dozen meters from the barrel end, the diameter of the base of the cone exceeds one meter. This results in individual pellets occasional hitting non-target birds. In addition, inaccurate shots injure birds with single pellets (22). To hit a duck in fast flight, one has to aim as much as a few meters in front of it. Among hunters there is the saying "one packet, one duck," which means that a packet of ammunition ( 25 cartridges) needs to be fired to hit a single duck. In addition to injuries caused by the projectile, animals are also poisoned by lead entering the bloodstream from the pellets in their body $(8,20,48)$. Birds from various parts of Europe, including Poland, found dead on wintering grounds had lead pellets in their bodies (also in their stomach) $(22,44)$. This clearly demonstrates the negative impact of hunting on the survival of birds, and thus the negative impact on the natural environment. Injured and lead-poisoned birds become easy prey for predators $(16,34,38,49)$. Predators and scavengers eating these dead or weakened birds are also poisoned in their turn and often die $(6,32,40)$.

The negative consequences of hunting with lead ammunition do not affect only game animals. The impact extends to other organisms living in hunting areas, and often to animals living in places very distant from these areas, since most game birds belong to migratory species $(16,22,25,38,44)$. The negative influence of lead ammunition on game birds has been conclusively confirmed by numerous observations and field studies $(8,11,24,54,58-62)$. The above facts, as well as the currently applicable law, must be known to veterinarians. Therefore, according to the law (including the code of ethics), veterinarians are not allowed to participate in this kind of hunting. It is worth adding that there is a directive requiring the protection of wild birds within the European Union (17).

Another negative aspect of bird hunting with lead shot is the shooting of species that have no economic significance and are not a threat to the balance in their living environments (22). In Poland, this applies in particular to hazel grouse, partridge, common teal, common pochard, tufted duck, common wood pigeon, coot and Eurasian woodcock. It is difficult to find a reason for hunting for tiny woodcocks other than to boast of shooting such a bird. It seems that obtaining tiny feathers of woodcock as hunting trophies (so-called painting feathers) should be a source of shame rather than pride, in particular for hunting veterinarians.

In the case of pheasants, it is necessary to consider the ethical aspect of hunting. These birds are bred in aviaries and special breeding centers and released into hunting grounds in early autumn (51). This practice would be commendable if we ignored its purpose. These birds are hunted from the beginning of October each year. Birds from aviaries are easy targets for hunters because they are not familiar with the area in which they are released and they are not adapted to life in the new environment. Participation in such hunting seems to be directly contrary to the Act on the Profession of the Veterinary Surgeon and, in the authors' opinion, to the ethics of hunting, as well (1).

Another problem raised by opponents of hunting stems from the fact that certain species of ducks, in particular mallard and common teals, are game animals, while garganeys (Spatula querquedula) are protected 
birds. A garganey is slightly smaller than a mallard and a little bigger than a common teal. For this reason, it is difficult to quickly determine the species of a bird at the beginning of the hunting season (mid-August), when birds hatched in the current year have not yet reached their full size. In the case of battue hunting or night hunting, such recognition is virtually impossible (52). The authors know of cases of shooting, during collective hunts, at such characteristic and easily recognizable ducks as the northern shoveler (Anas clypeata), which is a protected species. Organizations for protection of animals reveal cases of hunters killing protected birds and posting their photos in social media (https:// oko.press/mysliwa-zabila-cyranke-to-gatunek-scislechroniony/). Out of all the game duck species, the only one of any economic importance, albeit marginal, is the mallard duck. Since these birds can only be shot in flight, it is worth pointing out that they are usually shot in the pectoral muscles. These muscles, which are the largest edible part of ducks, most often contain from a few to a dozen or so pellets or wounds caused by pellets. Lead is deposited around the edges of wound canals and enters the human body during consumption $(5,23,26,27,29,42,61,62)$. What is important, some culinary procedures, such as adding vinegar or wine to meat, often facilitate the absorption of lead from duck meat by the human body $(18,43,45)$.

Veterinarians are obliged to protect public health. The harmfulness of bird meat obtained by hunting with lead shot is an argument not only against this type of hunting, but also against the consumption of such meat. The results of tests for lead content in the meat of game birds indicate high Pb levels $(10,44,46,56)$, often in excess of $0.1 \mathrm{mg} / \mathrm{g}$, which in the case of meat from farm animals would disqualify such food as unfit for human consumption $(15,17,19)$.

Lead is a foreign element in the natural environment $(4,13)$. It is believed that the smallest amounts of this metal are toxic to living organisms (13). They negatively affect the functioning of the nervous system, including intellectual development $(4,12,14,35$, $55)$. Lead poisoning in humans after consumption of meat of animals obtained through hunting with lead ammunition is described in the scientific literature $(10$, $26,30,33,36,41,46,56)$.

The facts and arguments presented here unequivocally indicate that some forms of hunting, and bird hunting in particular, are in conflict with legal provisions regarding veterinary surgeons. The law obliges veterinary surgeons to actively oppose such practices.

In practice, it is impossible to charge hunting veterinarians and bring them to justice. The collection of evidence would be possible only during hunting, and participation in hunting is not possible for bystanders.

The legal obligation of veterinarians to actively oppose practices threatening the natural environment is also a dead letter because of the lack of sanctions for failure to oppose such practices.
Regardless of the ethical attitude of hunting veterinarians, hunting cannot be regarded as positive, but it is not prohibited for veterinarians to hunt in accordance with applicable normative acts. At the same time, the law directly prohibits veterinarians from activities that can cause environmental damage. Members of this profession should therefore refrain from certain forms of hunting, in particular from hunting for game birds. Veterinarians, in particular those who are hunters, should actively oppose such forms of hunting that are harmful to the natural environment, especially hunting for game birds with the use of lead ammunition.

In accordance with veterinary knowledge, ethics and deontology, all veterinarians should inform the public about the harmfulness of eating game animals obtained by shooting with lead ammunition, in particular with lead pellets.

\section{References}

1. Act of 13 October 1995 hunting law. Dz. U. 2018 item 2033; 2019 item 125, 730, 879. http://prawo.sejm.gov.pl/isap.nsf/download.xsp/WDU19951470713/U/ D19950713Lj.pdf

2. Act of 21 December 1990 about the profession of veterinary surgeon and chambers of veterinary medicine. Dz. U. 2019 item 1140. http://prawo.sejm. gov.pl/isap.nsf/download.xsp/WDU19910080027/U/D19910027Lj.pdf

3. Act of 27 April 2001 environmental Protection Law. (Dz. U. 2019 item 1396 1403, 1495, 1501, 1527, 1579, 1680, 1712, 1815, 2087, 2166. http://prawo. sejm.gov.pl/isap.nsf/download.xsp/WDU20010620627/U/D20010627Lj.pdf

4. Ahamed M., Siddiqui M. K. J.: Environmental lead toxicity and nutritional factors. Clin. Nutr. 2007, 26, 400-408.

5. Andreotti A., Borghesi F., Aradis A.: Lead ammunition residues in the meat of hunted woodcock: a potential health risk to consumers. Ital. J. Anim. Sci. 2016, 15, 22-29.

6. Andreotti A., Fabbri I., Menotta S., Borghesi F.: Lead gunshot ingestion by a peregrine falcon. 6rdeola $2018,65,53-58$.

7. Andreotti A., Guberti V., Nardelli R., Pirrello S., Serra L., Volponi S., Green $R$. E.: Economic assessment of wild bird mortality induced by the use of lead gunshot in European wetlands. Sci. Total. Environ. 2018, 610-611, 1505-1513.

8. Binkowski E. J., Sawicka-Kapusta K.: Lead poisoning and its in vivo biomarkers in Mallard and Coot from two hunting activity areas in Poland. Chemosphere 2015, 127, 101-108.

9. Binkowski L. J., Sawicka-Kapusta K., Szarek J., Strzyżewska E., Felsmann M. Z.: Histopathology of liver and kidney of wild living Mallards Anas platyrhynchos and Coots Fulica atra with considerably concentrations of lead and cadmium. Sci. Total. Environ. 2013, 450-451, 326-333.

10. Bjerregaard P., Johansen P., Mulvad G., Pedersen H. S., Hansen J. C.: Lead sources in human diet in Greenland. Environ Health Perspect. 2004, 112, 1496-1498.

11. Brewer L., Fairbrather A., Clark J., Amick D.: Acute toxicity of lead, steel, and an iron-tungsten-nickel shot to mallard ducks (Anas platyrhynchos). J. Wild. Dis. 2003, 39, 638-648.

12. Canfield R. L., Henderson Jr C. R., Cory-Slechta D. A., Cox C., Jusko T. A., Lanphear B. P.: Intellectual impairment in children with blood lead concentrations below $10 \mu \mathrm{g}$ per deciliter. N. Engl. J. Med. 2003, 348, 1517-1526.

13. Carlisle J. C., Dowling K. C., Siegel D. M., Alexeeff G. V.: A blood lead benchmark for assessing risks from childhood lead exposure. J. Envirn. Sci. Health. A Tox. Hazard Subst. Environ. Eng. 2009, 44, 1200-1208.

14. Chandramouli K., Steer C. D., Ellis M., Emond A. M.: Effects of early childhood lead exposure on academic performance and behaviour of school age children. Arch. Dis. Child. 2009, 94, 844-848.

15. Commission Regulation (EC) No 466/2001 of $8^{\text {th }}$ March 2001 setting the maximum levels for certain contaminants in foodstuffs. Off. J. Europ. Commiss. 16.3.2001, L77/1-L77/13.

16. Degernes L., Heilman S., Trogdon M., Jordan M., Davison M., Kraege D., Correa M., Cowen P.: Epidemiologic investigation of lead poisoning in trumpeter and tundra swans in Washington state, USA, 2000-2002. J. Wildl. Dis. 2006, 42, 345-358.

17. Directive 2009/147/EC of the European Parliament and of the Council of 30 November 2009 on the conservation of wild birds. Off. J. Europ. Commiss. $5020 / 7$. 
18. EFSA (European Food Safety Authority). Scientific opinion on lead in food. European Food Safety Authority Journal 2010, 8, 1570. https://doi. org/10.2903/j.efsa.2010.1570

19. European Commission. Regulation (EC) No 1881/2006 of 1 December 2006 on eating maximum levels for certain contaminants in foodstuffs. Off. J. Europ. Union 20.12.2006, L364/5-L364/24; 2006.

20. Felsmann M. Z., Skibniewska K., Szarek J., Gesek M.: Morphological pattern of internal organs in mallard ducks (Anas platyrhynchos L.) from an intensive hunting area. Fres. Environ. Bull. 2010, 19, 322-326.

21. Felsmann M., Szarek J.: Analysis of the legal status of hunting in Poland and the ethics of hunting veterinarians. Życie Wet. 1996, 71, 172-175.

22. Felsmann M. Z., Szarek J.: Waterfowl hunting in the context of lead contamination and ethically non-conforming conduct. J. Elem. 2015, 20, 785-796.

23. Felsmann M. Z., Szarek J., Felsmann M., Gulda D.: Lead in game bird meat as a risk to public health: new aspects in the light of physical phenomena generated by a projectile. J. Elem. 2016, 21, 595-607.

24. Ferreyra H., Romano M., Beldomenico P., Caselli A., Correa A., Uhart M.: Lead gunshot pellet ingestion and tissue lead levels in wild ducks from Argentine hunting hotspots. Ecotox Environ. Safe 2014, 103, 74-81.

25. Figuerola J., Mateo R., Green A. J., Mondain-Monval J.-Y., Lefranc H., Mentaberre $G$.: Grit selection in waterfowl and how it determines exposure to ingested lead shot in Mediterranean wetlands. Environ. Conserv. 2005, 32, 226-234.

26. Green R. E., Pain D. J.: Potential health risks to adults and children in the UK from exposure to dietary lead in gamebirds shot with lead ammunition. Food Chem. Toxicol. 2012, 50, 4180-4190.

27. Guitard R., Serratosa J., Thomas V. G.: Lead-poisoned wildfowl in Spain: a significant threat for human consumers. Int. J. Environ. Health Res. 2002, 12, 301-309.

28. Haig S. M., D'Elia J., Eagles-Smith C., Fair J. M., Gervais J., Herring G., Rivers J. W., Schulz J. H.: The persistent problem of lead poisoning in birds from ammunition and fishing tackle. Condor 2014, 116, 408-428.

29. Haldimann M., Baumgartner A., Zimmerli B.: Intake of lead from game meat - a risk to consumers' health? Eur. Food Res. Technol. 2002, 215, 375-379.

30. Hanning R. M., Sandhu R., MacMillan A., Moss L., Tsuji L. J. S., Nieboer E. Impact on blood $\mathrm{Pb}$ levels of maternal and early infant feeding practices of First Nation Cree in the Mushkegowuk Territory of northern Ontario, Canada. J. Environ. Monit. 2003, 5, 241-245.

31. Houszka M.: Veterinary surgeon - hunter. Życie Wet. 2002, 77, 336-337.

32. Hunt W. G., Watson R. T., Oaks J. L., Parish C. N., Burnham K. K., Tucker R. L., Belthoff J. R., Hart G.: Lead bullet fragments in venison from rifle-killed deer: potential for human dietary exposure. PLos One 2009, 4, e5330.

33. Iqbal S., Blumenthal W., Kennedy C., Yip F. Y., Pickard S., Flanders W. D., Loringer K., Kruger K., Caldwell K. L., Brown M. J.: Hunting with lead: Association between blood lead levels and wild game consumption. Environ. Res. 2009, 109, 952-959.

34. Ishii Ch., Nakayama S. M. M., Ikenaka Y., Nakata H., Saito K., Watanabe Y., Mizukawa H., Tanabe S., Nomiyama K., Hayashi T., Ishizuka M.: Lead exposure in raptors from Japan and source identification using $\mathrm{Pb}$ stable isotope ratios. Chemosphere 2017, 186, 367-373

35. Jakubowski M.: Low-level environmental lead exposure and intellectual impairment in children - the current concepts of risk assessment. Int. J. Occup Med. Environ. Health 2012, 24, 1-7.

36. Johansen P., Asmund G., Riget F.: High human exposure to lead through consumption of birds hunted with lead shot. Environ. Pollut. 2004, 127, 125-129.

37. Kanstrup N., Swift J., Stroud D. A., Lewis M.: Hunting with lead ammunition is not sustainable: European perspectives. AMBIO 2018, 47, 846-857.

38. Kim J., Oh J. M.: Assessment of lead exposure in waterfowl species, Korea Arch. Environ. Contam. Toxicol. 2014, 67, 529-534.

39. Knott J., Gilbert J., Green R. E., Hoccom D. G.: Comparison of the lethality of lead and copper bullets in deer control operations to reduce incidental lead poisoning; field trials in England and Scotland. Conservation Evidence 2009, 6, 71-78.

40. Knott J., Gilbert J., Hoccom D. G., Green R. E.: Implications for wildlife and humans of dietary exposure to lead from fragments of lead rifle bullets in deer shot in the UK. Sci. Total Environ. 2010, 409, 95-99.

41. Lazarus M., Crnić A. P., Bilandžić N., Kusak J., Reljić S.: Cadmium, lead, and mercury exposure assessment among Croatian consumers of free-living game. Are. Hig. Rada. Toxicol. 2014, 65, 281-292.

42.Martin A., Müller-Graf Ch., Selhorst T., Gerofke A., Ulbig E., Gremse C., Greiner M., Lahrssen-Wiederholt M., Hensel A.: Comparison of lead levels in edible parts of red deer hunted with lead or non-lead ammunition. Sci. Total Environ. 2019, 653, 315-326.
43. Mateo R., Baos A. R., Vidal D., Camarero P. R., Martinez-Haro M., Taggart $M$. A.: Bioaccessibility of $\mathrm{Pb}$ from ammunition in game meat is affected by cooking treatment. PLoS ONE 2011;6:e15892.

44. Mateo R., Green J., Lefranc H., Baos R., Figuerola J.: Lead poisoning in wild birds from southern Spain: A comparative study of wetland areas and species affected, and trends over time. Ecotox Environ. Safe 2007, 66, 119-126.

45. Mateo R., Vallverdú-Coll N., López-Antia A., Taggart M. A., MartínezHaroa M., Guitart R., Ortiz-Santaliestra M. E.: Reducing Pb poisoning in birds and $\mathrm{Pb}$ exposure in game meat consumers: The dual benefit of effective $\mathrm{Pb}$ shot regulation. Environ. Intern. 2014, 63, 163-168.

46. Meltzer H. M., Dahl H., Brantsaeter A. L., Birgisdottir B. E., Knutsen H. K., Bernhof A., Oftedal B., Lande U. S., Alexander J., Haugen M., Ydersbond T. A.: Consumption of lead-shot cervid meat and blood lead concentrations in a group of adult Norwegians. Environ. Res. 2013, 127, 29-39.

47. Mieczkowski J.: Hunting and veterinary ethics. Życie Wet. 2002, 77, 557-558.

48. Pain D. J., Cromie R. L., Newth J., Brown M. J., Crutcher E., Hardman P., Hurst L., Mateo M., Meharg A. A., Moran A. C., Raab A., Taggart M. S. A., Green R. E.: Potential hazard to human health from exposure to fragments of lead bullets and shot in the tissues of game animals. PLoS One 2010, 5, e10315.

49. Plaza P. I., Lambertucci S. A.: What do we know about lead contamination in wild vultures and condors? A review of decades research. Sci. Total. Environ. 2019, 654, 409-417.

50. Regulation of 11 March 2005 Ministry of Environment Regulation on the establishment of a list of game species. Dz. U. 2005 No 45 item 433. http:// prawo.sejm.gov.pl/isap.nsf/download.xsp/WDU20050450433/O/D20050433. pdf

51. Regulation of 16 March 2005 Ministry of Environment Regulation on the determination of hunting periods for game animals. Dz. U. 2005 No 48 item 459. http://prawo.sejm.gov.pl/isap.nsf/download.xsp/WDU20050480459/O/ D20050459.pdf

52. Regulation of 23 March 2005. Ministry of Environment on the detailed conditions for carrying out hunting and marking of carcasses. Dz. U. 2005 No 61 item 548. http://prawo.sejm.gov.pl/isap.nsf/download.xsp/WDU20050610548/O/ D20050548.pdf

53. Romano M., Ferreyra H., Ferreyroa G., Molina F. V., Caselli A., Barberis I., Beldoménico $P$., Uhart $M$.: Lead pollution from waterfowl hunting in wetlands and rice fields in Argentina. Sci. Total Environ. 2016, 545, 104-113.

54. Sanders T., Liu Y., Buchner V., Tchounwou P. B.: Neurotoxic Effects and Biomarkers of Lead Exposure: A Review. Rev. Environ. Health. 2009, 24, $15-45$.

55. Schnaas L., Rothenberg S. J., Flores M.-F., Martinez S., Hernandez C. Osorio E., Velasco S. R., Perroni E.: Reduced Intellectual Development in Children with Prenatal Lead Exposure. Environ. Health Persp. 2006, 114 791-797.

56. Taggart M. A., Reglero M. M., Camarero P. R., Mateo R.: Should legislation regarding maximum $\mathrm{Pb}$ and $\mathrm{Cd}$ levels in human food also cover large game meat? Environ. Intern. 2011, 37, 18-25.

57. The Constitution of the Republic of Poland of April 2, 1997 adopted by the National Assembly on April 2, 1997, adopted by the Nation in a constitutional referendum on May 25, 1997, signed by the President of the Republic of Poland on July 16, 1997 (Dz. U. 1997 No 78 item 483; 2001 No 28 item 319; 2006 No 200 item 1471; 2009 No 114 item 946). http://prawo.sejm.gov.pl/isap.nsf/ download.xsp/WDU19970780483/U/D19970483Lj.pdf

58. Thomas V. G., Gremse C., Kanstrup N.: Non-lead rifle hunting ammunition: issues of availability and performance in Europe. Eur. J. Wildl. Res. 2016, 62, 633-641.

59. Thomas V. G., Guitart R.: Limitations of European Union policy and law for regulating use of lead shot and sinkers: comparisons with North American regulation. Env. Pol. Gov. 2010, 20, 57-72.

60. Tong S., von Schirnding Y. E., Prapamonto T.: Environmental lead exposure: a public health problem of global dimensions. Bull. World Health Organ. 2000, 78, 1068-1077.

61. Tsuji L. J., Wainman B. C., Jayasinghe R. K., Van Spronsen E. P., Liberda $E$. $N$.: Determining tissue-lead levels in large game mammals harvested with lead bullets: human health concerns. Bull. Environ. Contam. Toxicol. 2009, 82, 435-439.

62. Tsuji L. J., Wainman B. C., Martin I. D., Sutherland C., Weber J.-P., Dumas P., Nieboer E.: Lead shot contribution to blood lead of First Nations people: The use of lead isotopes to identify the source of exposure. Sci. Total Environ. 2008, 405, 180-185.

Corresponding author: Dr Mariusz Z. Felsmann, Katedra Nauk Podstawowych i Przedklinicznych, Instytut Medycyny Weterynaryjnej, UMK Toruń, ul. Gagarina 7, 87-100 Toruń, Poland; e-mail: felsmann.mariusz@wp.pl 